\title{
Kemandirian dan Motivasi Belajar Siswa Terhadap Prestasi Belajar Program Keahlian Akuntansi Di SMK Negeri 1 Sidenreng Rappang
}

\author{
Sahade \\ Pendidikan Akuntansi, Universitas Negeri Makassar \\ Email: sahade@unm.ac.id
}

\begin{abstract}
This study aims to determine the effect of independence and learning motivation on student achievement in accounting expertise program at SMK Negeri 1 Sidrap. The population in this study were 66th grade students of the Accounting Skills Program, amounting to 66 students. Data analysis used descriptive analysis, classic assumption test, instrument test and hypothesis test with non-parametric statistics. The results of this study indicate that learning independence and motivation influence student achievement with a significant level $<0.05$. The coefficient of determination $\left(\mathrm{R}^{2}\right)$ is 0.538 or 53.8 percent. This means that students who have high independence and motivation to learn in accounting subjects will be able to improve student learning achievement itself by 53.8 percent while the remaining 46.2 percent is influenced by other factors beyond observation in this study. The increase in student achievement is dominated by learning independence with a coefficient of determination of 0.471 or 47 percent.
\end{abstract}

Keywords: Independence of Learning; Motivation To Learn; Student Achievement

\begin{abstract}
Abstrak. Penelitian ini bertujuan untuk mengetahui pengaruh kemandirian dan motivasi belajar terhadap prestasi belajar siswa program keahlian akuntansi di SMK Negeri 1 Sidrap. Populasi dalam penelitian ini adalah siswa kelas XI Program Keahlian Akuntansi yang berjumlah 66 orang siswa. Analisis data menggunakan analisis deskriptif, uji asumsi klasik, uji instrument dan uji hipotesis dengan statistika non parametrik. Hasil penelitian ini menunjukkan bahwa kemandirian belajar dan motivasi berpengaruh terhadap prestasi belajar siswa dengan tingkat signifikan $<0,05$. Nilai koefisien determinasi $\left(\mathrm{R}^{2}\right)$ sebesar 0,538 atau 53,8 persen. Artinya siswa yang memiliki kemandirian dan motivasi belajar yang tinggi pada mata pelajaran akuntansi akan dapat meningkatkan prestasi belajar siswa itu sendiri sebesar 53,8 persen sedangkan sisanya 46,2 persen dipengaruhi oleh faktor lain diluar pengamatan dalam penelitian ini. Kenaikan hasil prestasi belajar siswa di dominasi oleh kemandirian belajar dengan koefisien determinasi 0,471 atau 47 persen.
\end{abstract}

Kata Kunci: Kemandirian Belajar; Motivasi Belajar; Prestasi Belajar Siswa

\section{PENDAHULUAN}

Pendidikan memegang peranan yang sangat penting dalam proses peningkatan kualitas sumber daya manusia. Upaya peningkatan kualitas sumber daya manusia dapat dilaksanakan melalui beberapa jalur pendidikan antara lain yaitu pendidikan formal, pendidikan non formal dan pendidikan informal. Sumber daya manusia yang berkualitas dapat dicapai apabila pendidikan diselenggarakan secara komprehensif dan berkarakter (Rahmatullah \& Inanna, 2017).

Sekolah merupakan lembaga pendidikan formal yang memegang peran penting dalam meningkatkan kualitas sumber daya manusia suatu bangsa. Sebab melalui sekolah dapat dihasilkan lulusan yang memiliki berbagai kompetensi yang sesuai dengan tujuan masingmasing jenjang pendidikan. Kualitas pendidikan salah satunya dipengaruhi oleh kualitas proses belajar mengajar dikelas yang merupakan bagian pokok dari pendidikan. Pendidikan harus mampu melahirkan generasi bermutu yang dapat diandalkan dalam menciptakan kedaulatan ekonomi, sehingga mampu mengelola dan memanfaatkan potensi sumber daya alam secara optimal untuk kemakmuran rakyat (Rahmatullah, 2018).

Pelaksanaan kegiatan pembelajaran dalam kelas melibatkan guru sebagai pendidik dan siswa sebagai peserta didik. Baik guru maupun siswa memiliki peranan penting dalam kegiatan pembelajaran tersebut demi tercapainya tujuan pembelajaran yang telah ditetapkan. Guru berperan untuk membimbing anak didik mencapai tujuan pembelajaran, guru mengarahkan setiap kegiatan pembelajaran dan mengarahkan siswa untuk menyelesaikan tugas- 
tugas yang diberikan (Rahmatullah \& Inanna, 2018). Pada proses perkembangannya, berhasil atau tidaknya suatu proses pendidikan salah satunya ditentukan oleh kompetensi yang dimiliki oleh guru, dalam hal ini guru berperan sebagai fasilitator yang bertugas untuk mengoptimal keaktifan dan kreatifitas siswa (Yulianti, Thaief, \& Rahmatullah, 2019). Menurut Parmell dalam Johnson (2009) pembelajaran mandiri dapat menjadikan siswa berhasil.

Sementara Silberman (2014) mengemukakan bahwa belajar dengan pengarahan sendiri sering lebih mendalam dan lebih permanen daripada dengan pengarahan pengajar (guru).

Desmita (2017:185) berpendapat bahwa kemandirian belajar adalah kemampuan untuk mengandalkan dan mengatur pikiran, perasaan dan tindakan sendiri secara bebas serta berusaha sendiri untuk mengatasi perasaan-perasaan malu dan keraguan- keraguan. Kemandirian belajar menuntut tanggung jawab yang besar bagi diri siswa sehingga berusaha melakukan berbagai kegiatan untuk tercapainya tujuan belajar. Siswa dikatakan telah mampu belajar secara mandiri apabila telah melakukan tugas belajar tanpa tergantung pada orang lain.

Seorang siswa dengan kemandirian belajar tinggi yang ditandai dengan adanya tanggung jawab belajar yang tinggi dapat meningkatkan kualitas belajarnya, secara otomatis akan mendukung pencapaian tujuan pembelajaran. Dengan tercapainya tujuan pembelajaran dapat menunjang siswa untuk memperoleh prestasi belajar yang maksimal.

Selain kemandirian belajar siswa, hal lain yang berpengaruh terhadap prestasi belajar siswa yaitu motivasi belajar siswa. Menurut Uno (2017) motivasi belajar merupakan pengarah untuk perbuatan belajar kepada tujuan yang jelas yang diharapkan dapat dicapai.

Sadirman (2011) berpendapat bahwa motivasi belajar adalah keseluruhan daya penggerak dalam diri siswa yang menimbulkan kegiatan belajar, yang menjamin kelangsungan kegiatan belajar dan memberikan arah pada kegiatan belajar sehingga tujuan yang dikehendaki oleh subyek belajar itu dapat tercapai.

Motivasi memiliki peran penting terhadap proses belajar, tinggi rendahnya motivasi belajar selalu dijadikan indikator baik buruknya prestasi belajar seorang siswa. Dengan adanya motivasi, siswa akan terdorong untuk belajar serta DOI:10.26858/jekpend.v3i2.14320 menyenangi mata pelajaran dan dengan senang hati mempelajari pelajaran tersebut. Siswa yang memiliki motivasi tinggi cenderung lebih bersemangat dalam belajar dibandingkan siswa yang tidak memiliki motivasi dalam belajar.

Seberapapun tingginya intelektual siswa jika siswa tidak memiliki motivasi maka proses pembelajaran tidak akan berlangsung secara optimal. Motivasi belajar siswa dapat menjadi lemah dan lemahnya motivasi atau tiadanya motivasi belajar akan melemahkan kegiatan, sehingga mutu prestasi belajar menjadi rendah.

Menurut Syah (2012) prestasi belajar adalah tingkat keberhasilan siswa dalam mencapai tujuan yang ditetapkan dalam sebuah program. Prestasi belajar merupakan realisasi atau pemekaran dari kecakapan-kecakapan potensial atau kapasitas yang dimiliki seseorang. Dalam prestasi belajar siswa dipengaruhi oleh beberapa faktor, baik berasal dari dalam diri sendiri maupun faktor dari luar dirinya.Menurut Syah (2012) faktor-faktor yang mempengaruhi prestasi belajar siswa adalah:

1) Faktor internal (faktor dari dalam siswa) yang meliputi 2 aspek, yakni:

(a) Aspek fisiologis (bersifat jasmani).

(b) Aspek psikologis (bersifat rohaniah).

2) Faktor eksternal (faktor dari luar siswa) meliputi 2 aspek, yakni:

(a) Lingkungan sosial, yaitu orang tua dan keluarga, guru dan staf, teman, masyarakat dan tetangga.

(b) Lingkungan nonsosial, yaitu: gedung sekolah dan letaknya, keadaan rumah, peralatan, alam.

Berdasarkan pendapat di atas terdapat berbagai faktor yang mempengaruhi hasil belajar. Oleh sebab itu, dalam penelitian ini peneliti mengambil dua faktor yang mempengaruhi hasil belajar siswa yaitu faktor internal dalam hal ini kemandirian belajar siswa dan motivasi belajar siswa.

SMK Negeri 1 Sidenreng Rappang merupakan salah satu sekolah menengah kejuruan di Kabupaten Sidenreng Rappang yang menjadi salah satu sekolah favorit. Sekolah ini terus berupaya mencetak lulusan yang siap untuk bekerja dan bersaing di dunia kerja. Salah satu upaya dalam menghadapi tantangan tersebut dengan meningkatkan prestasi belajar dan kualitas lulusannya melalui peningkatan keterampilan pencatatan dan pelaporan keuangan (akuntansi). Selain secara manual juga penguasaan aplikasi dasar akuntansi. Sistem pencatatan penjualan dan proses transaksi 
keuangan dapat dilakukan dengan menggunakan aplikasi digital misalnya Accounting Point of Sale yang terintegrasi dengan web (Rahmatullah et al., 2020).

Peningkatan ini dilakukan pada semua program keahlian yang ada di SMK Negeri 1 Sidenreng Rappang utamanya program keahlian akuntansi.

Berdasarkan hasil observasi awal yang peneliti lakukan di SMK Negeri 1 Sidenreng Rappang khususnya siswa kelas XI program keahlian akuntansi. fakta yang ada bahwa kemandirian belajar siswa masih rendah, hal ini terlihat pada saat pembelajaran berlangsung sebagian besar siswa hanya mengandalkan pembelajaran yang disampaikan oleh guru yang mengajar dalam kelas. Selain itu, banyaknya siswa yang belum mampu belajar mandiri tanpa harus dibimbing oleh guru, hal ini terlihat pada saat guru tidak masuk kelas banyak siswa yang belum mampu memanfatkan waktu luang untuk belajar dan mengerjakan tugas yang diberikan oleh guru. Selain itu, motivasi belajar siswa juga masih rendah, hal ini juga terlihat saat pembelajaran siswa hanya ada beberapa siswa yang terlihat cukup antusias dan yang lain hanya bercerita dengan temannya serta sibuk dengan kegiatan masing-masing.

Berikut ini gambaran mengenai kemandirian belajar siswa dan keterampilan mengajar guru selama proses belajar mengajar serta hasil belajar siswa, data yang diperoleh dari 32 responden dengan menggunakan kuesioner dan dokumentasi.

Tabel 1 menunjukkan bahwa kemandirian belajar dan motivasi belajar program keahlian akuntansi SMK Negeri 1 Sidenreng Rappang pada mata pelajaran akuntansidikatakan masih kurang karena hasil persentase rata-rata setiap indicator yang diperoleh masih dibawah kategori baik (68,01persen $\geq \mathrm{B} \leq 84,00$ persen) sesuai dengan pendapat Narimawati (2008) yang didasarkan pada kriteria persentase tanggapan responden.

Pada variable motivasi belajar siswa terdapat lima indikator, kelima indikator masih berada dibawah kategori baik dengan persentase rata-rata sebesar 52 persen Dua indikator diantaranya di atas peresentase rata-rata yaitu mampu mengambil keputusan 56 persen dan hasrat atau keinginan kuat untuk belajar sebesar 54persen Sementara terdapat tiga indikator yang masih berada di bawah rata-rata, diantaranya percaya diri dalam melaksanakan tugas sebesar DOI:10.26858/jekpend.v3i2.14320
51 persen inisiatif dalam menghadapi masalah belajar sebesar 49 persen dan tanggung jawab atas apa yang dilakukannya sebesar 49 persen.

Table 1. Tingkatan Kemandirian Belajar Siswa dan Motivasi Belajar Siswa serta Prestasi Belajar Siswa pada Mata Pelajaran Akuntasi Semester Genap Kelas XI Akuntansi SMK Negeri 1 Sidenreng Rappang 2018/2019

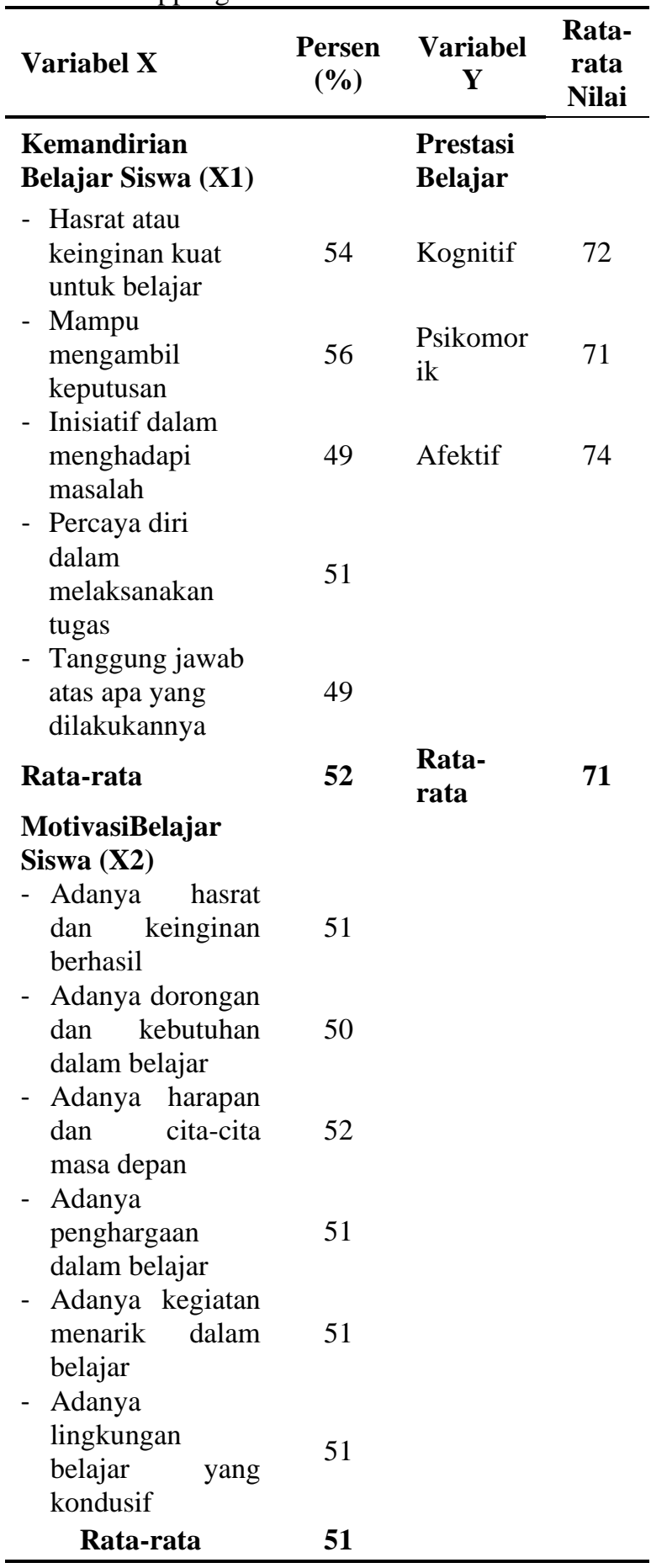

Sumber: Olah Data Penelitian 2019

Selanjutnya variabel motivasi belajar siswa memiliki enam indikator, semua indikator 
masih berada dibawah kategori baik dengan persentase rata-rata sebesar 51 persen Lima indikator diantaranya berada diatas persentase rata-rata yaitu adanya harapan dan cita-cita masa depan sebesar 52 persen adanya hasrat dan keinginan berhasil sebesar 51 persen adanya penghargaan dalam belajar sebesar 51 persen adanya kegiatan menarik dalam belajar sebesar 51 persen dan adanya lingkungan belajar yang kondusif sebesar 51 persen Sedangkan satu indikator lainnya masih dibawah rata-rata, yaitu adanya dorongan dan kebutuhan dalam belajar sebesar 50 persen.

Terkait prestasi belajar siswa, terdapat ketentuan bahwa untuk mengukur prestasi belajar siswa, ditentukan berdasarkan Kriteria Ketuntasan Minimal (KKM) yang ditetapkan adalah 75, yang digunakan sebagai patokan yang menyatakan nilai rapor kelas XI program keahlian akuntansi SMK Negeri 1 Sidenreng Rappang. Prestasi belajar yang diukur dengan nilai rapor semester genap siswa kelas XI program keahlian akuntansi SMK Negeri 1 Sidenreng Rappang dikatakan masih kurang karena rata-rata nilai yang diperoleh masih dibawa standar ketuntasan yang ditetapkan. Hal ini dapat dilihat dari nilai prestasi belajar yang diperoleh kognitif dengan rata-rata 72 , nilai afektif dengan rata-rata 74 dan psikomotorik dengan rata-rata 74 .

Berdasarkan uraian di atas, maka penulis tertarik untuk melakukan penelitian yang berjudul "Kemandirian Belajar dan Motivasi Belajar terhadap Prestasi Belajar Siswa Program Keahlian Akuntansi di SMK Negeri 1 Sidenreng Rappang".

\section{METODE PENELITIAN}

Penelitian ini dilakukan untuk mengetahui: 1) mengetahui pengaruh kemandirian belajar dan motivasi belajar terhadap prestasi belajar siswa program keahlian akuntansi di SMK Negeri 1 Sidenreng Rappang baik secara parsial maupun secara simultan; 2) Mengetahui yang mana yang paling dominan kedua variable bebas tersebut pengaruhnya terhadap variable terikat.

Populasi dan sampel dalam penelitian ini adalah siswa-siswi Kelas XI Program Keahlian Akuntansi di SMK Negeri 1 Sidenreng Rappang, dengan populasi sebanyak 66 siswa dengan menggunakan sampling jenuh dimana banyaknya sampel sama dengan populasi yakni sebanyak 66 siswa yang tersebar di empat kelas yakni kelas XI Akuntansi.

DOI:10.26858/jekpend.v3i2.14320
Jenis dan Sumber data yang dipergunakan dalam penelitian ini adalah data kualitatif mengenai kemandirian belajar, motivasi belajar dan prestasi belajar siswa kelas XI Program Keahlian Akuntansi. Sedangkan sumber datanya adalah data primer menyangkut hasil pengamatan serta wawancara langsung dengan responden, dengan menggunakan instrument dan kuesioner yang dibagikan kepada siswa-siswi Kelas XI Program Keahlian Akuntansi di SMK Negeri I Sidenreng Rappang.

Analisis data dilakukan dengan menggunakan analisis deskriptif, uji asumsi klasik, uji instrument dan uji hipotesis dengan statistika non parametrik.

\section{HASIL DAN PEMBAHASAN}

\section{Hasil Analisis Data}

Untuk menetapkan peringkat dalam variabel kemandirian belajar $\left(\mathrm{X}_{1}\right)$ dan motivasi belajar $\left(\mathrm{X}_{2}\right)$ dapat dilihat dari perbaikan antara skor aktual dengan skor ideal dengan rumus yang dicantumkan dalam Narimawati (2008) sebagai berikut:

$$
\text { Skor Aktual }=\frac{\text { Jumlah perolehan skor }}{\text { Skor Maksimum }} \times 100
$$

Keterangan:

a. Skor aktual adalah skor jawaban yang diperoleh dari seluruh responden atas kuesioner yang telah diajukan

b. Skor ideal adalah skor maksimum atau skor tertinggi yang mungkin diperoleh jika semua responden memilih jawaban dengan skor tertinggi.

Adapun kriteria interpretasi skor menurut Riduwan dalam Nureni (2011) adalah sebagai berikut:

Tabel 2. Kriteria Interpretasi Skor

\begin{tabular}{l|c}
\multicolumn{1}{c|}{ Keterangan } & Persentase Skor \\
\hline Sangat Tidak Baik & $0-20$ \\
Tidak Baik & $21-40$ \\
Cukup Baik & $41-60$ \\
Baik & $61-80$ \\
Sangat Baik & $81-100$ \\
\hline
\end{tabular}

Sumber: Riduawan dalam Nureni (2011:39)

Deskripsi dari masing-masing variabel berdasarkan jawaban responden terhadap setiap variabel dideskrpsikan sebagaimana berikut:

\section{a. Variabel Kemandirian belajar}

Berdasarkan data variabel kemandirian belajar $\left(\mathrm{X}_{1}\right)$ yang terkumpul dari hasil angket pada 66 siswa, dengan lima indikator 
kemandirian belajar yaitu Adanya hasrat atau keinginan yang kuat untuk belajar, mampu mengambil keputusan, inisiatif menghadapi masalah belajar, tanggungjawab atas apa yang dilakukannya, Percaya diri dan melaksanakan tugas secara mandiri.

Hasil persentase skor aktual kemandirian belajar siswa diperoleh persentase skor rata-rata sebesar 77,2 persenyang tergolong baik. Meskipun demikian masih terdapat indikator yang masih di bawah rata-rata persentase skor aktual yaitu indikator hasrat dan keinginan yang kuat untuk belajardengan persentase 74 persen yang menunjukkan bahwakurangnya rasa percaya diri siswa terhadap kemampuan yang dimilikinya, indikator tanggung jawab atas apa yang dilakukannya dengan persentase 70 persen yang menunjukkan kurangnya usaha siswa untuk mengembangkan potensinya dan indikator percaya diri dalam melaksakan tugas secara mandiri dengan persentase 76 persen yang menunjukkan bahwa siswa tidak memahami materi yang disampaikan oleh guru sehingga dapat memberikan jawaban atas pertanyaan yang disampaikan oleh guru.

\section{b. Variabel Motivasi Belajar}

Berdasarkan data variabel Motivasi Belajar $\left(\mathrm{X}_{2}\right)$ yang terkumpul dari hasil kuesioner pada 66 siswa, dengan enam indikator Motivasi Belajar yaitu Hasrat dan Keinginan belajar, Dorongan dan Kebutuhan dalam Belajar, Harapan dan Cita-Cita Masa Depan, Penghargaan dalam Belajar, Kegiatan yang Menarik dalam Belajar, dan Lingkungan Belajar Yang Kondusif.

Hasil persentase skor aktual motivasi belajar siswa diperoleh persentase skor rata-rata sebesar 82,2 persen yang tergolong baik. Meskipun demikian terdapat 2 indikator yang masih di bawah rata-rata persentase skor aktual yaitu indikator penghargaan dalam belajar dengan persentase 77persenyang menunjukkan bahwapenghargaan berupa pujian yang diberikan oleh siswa masih kurang disamping itu adanyalingkungan belajar yang kondusif dengan persentase 66persen yang menunjukkan bahwa siswa merasa situasi lingkungan tempat mereka belajar tidak mendukung.

\section{c. Variabel Prestasi belajar}

Data yang diajukan dalam variable prestasi belajar (Y) adalah nilai rapor siswa kelas XI Program Keahlian Akuntansi SMK Negeri 1 Sidenreng Rappang tahun ajaran 2018/2019 yang diperoleh dari nilai tes ujian semester genap siswa kelas XI Program Keahlian DOI:10.26858/jekpend.v3i2.14320
Akuntansi SMK Negeri 1 Sidenreng Rappang tahun ajaran 2018/2019 serta nilai yang diperoleh langsung dari guru yang bersangkutan yang berjumlah 66 siswa sebagai sampel dalam penelitian ini.

Untuk memudahkan pengklasifikasian prestasi belajar siswa kelas XI Akuntansi SMK Negeri 1 Sidenreng Rappang digunakan interval predikat. interval predikat yang digunakan untuk menggambarkan pengklasifikasian prestasi belajar siswa semester genap kelas XI Akuntansi program keahlian akuntansi SMK Negeri 1 Sidenreng Rappang tahun ajaran 2018/2019.

Berdasarkan hasil maka diperoleh hasil frekuensi terbanyak terdapat pada interval $81 \leq \mathrm{B} \leq 90$ sebanyak 56,1 persen atau 37 siswa yang berarti tergolong dalam kategori baik. Pada interval $91 \leq \mathrm{A} \leq 100$ sebanyak 33,3persen atau 22 siswa tergolong dalam kategori sangat baik. Sementara pada interval $75 \leq \mathrm{C} \leq 80$ hanya 10,6 persen atau 7 siswa yang tergolong dalam kategori cukup, dan pada interval <75 yang tergolong kurang, tidak terdapat siswa yang memperoleh nilai demikian. Hasil analisis deskriptif prestasi belajar dengan menggunakan SPSS versi 25 (terlampir) diketahui bahwa nilai rata-rata (mean) sebesar 88,36 yang mana nilai tersebut berada pada interval $81 \leq \mathrm{B} \leq 90$ berarti tergolong dalam kategori baik dengan standard deviasi sebesar 4,488. Berdasarkan penjelasan tersebut maka dapat disimpulkan bahwa nilai rapor semester genap siswa Program Keahlian Akuntansi di SMK Negeri 1 Sidenreng Rappang tahun ajaran 2018/2019 rata-rata baik serta tidak ada siswa yang memperoeh nilai di bawah Kriteria Ketuntasan Minimal yang telah ditentukan.

Analisis ini digunakan untuk mengetahui seberapa besar pengaruhvariabel bebas (independen) terhadap variabel terikat (dependen) baik secara bersama-sama (simultan) maupun secara parsial. Dalam penelitian ini, untuk mengetahui seberapa besar pengaruh kemandirian belajar $\left(\mathrm{X}_{1}\right)$ dan motivasi belajar $\left(\mathrm{X}_{2}\right)$, terhadap prestasi belajar belajar $(\mathrm{Y})$. Ringkasan hasil analisis regresi linear berganda dapat dijelaskan hasilnya sebagai berikut:

Berdasarkan hasil analisis diperoleh persamaan regresi:

$$
\begin{aligned}
& Y=a+b_{1} X_{1}+b_{2} X_{2} \\
& Y=22,313+0,502 X_{1}+0,371 X_{2}
\end{aligned}
$$$$
\text { Keterangan : }
$$

1. Konstanta sebesar 22,313 menyatakan bahwa jika variabel kemandirian belajar dan motivasi belajar dianggap sama dengan nol, 
maka variabel prestasi belajar sebesar 22,313

2. Koefisien kemandirian belajar $\left(b_{1} X_{1}\right)=$ 0,502 pada penelitian ini dapat diartikan bahwa variabel kemandirian belajar $\left(\mathrm{X}_{1}\right)$ berpengaruh positif terhadap prestasi belajar (Y). Hal ini menunjukkan bahwa jika variabel kemandirian belajar mengalami kenaikan satu-satuan, sementara variabel motivasi belajar tetap maka akan menyebabkan kenaikan prestasi belajar sebesar 0,502.

3. Koefisien motivasi belajar $\left(b_{2} X_{2}\right)=0,371$ pada penelitian ini dapat diartikan bahwa variabel motivasi belajar $\left(\mathrm{X}_{2}\right)$ berpengaruh positif terhadap prestasi belajar (Y). Hal ini menunjukkan bahwa jika variabel motivasi belajar mengalami kenaikan satu satuan, sementara variabel kemandirian belajar dianggap tetap maka akan menyebabkan kenaikan prestasi belajar sebesar 0,371.

Hasil Koefesien determinasi menunjukkan bahwa, nilai $\mathrm{R}^{2}$ adalah sebesar 0,538 atau 53,8persen. Hal ini berarti bahwa pengaruh kontribusi kemandirian belajar dan motivasi belajar terhadap prestasi belajar adalah sebesar 53,8persen sedangkan sisanya sebesar 46,2persen dipengaruhi oleh faktor lain yang ikut mempengaruhi dalam penentuan naik atau turunnya prestasi belajar karena selain dari kemandirian belajar dan motivasi belajar masih banyak faktor-faktor lain yang ikut mempengaruhi prestasi belajar contohnya faktor lingkungan, faktor fisiologis, faktor psikologis dan faktor lainnya.

Hasil Uji $\mathrm{F}$ diketahui bahwa $\mathrm{F}$ hitung sebesar 36.641 lebih besar dibandingkan $\mathrm{F}$ tabel. F tabel diperoleh sebesar 3,14 dengan taraf signifikan $0,000<0,05$. Untuk menguji hipotesis dilakukan dengan membandingkan antara $\mathrm{F}$ hitung dengan $\mathrm{F}$ tabel, kriteria pengujian yaitu:

1) Tolak H0, terima H1 jika nilai Fhitung>Ftabel pada taraf signifikan 0,05.

2) Tolak H1, terima H0 jika nilai Fhitung $<$ Ftabel pada taraf signifikan 0,05 .

Dari F tabel diperoleh sebesar 3,14 dengan demikian nilai $F$ hitung sebesar 36.641lebih besar dibandingkan $\mathrm{F}$ tabel dengan taraf signifikan sebesar 0,000 lebih kecil dari $\mathrm{a}=$ 0,05 . Hal ini berarti bahwa hipotesis diterima ataudengan kata lain kemandirian belajar dan motivasi belajarsecara simultan berpengaruh positif dan signifikan terhadap prestasi belajar

DOI:10.26858/jekpend.v3i2.14320 siswa kelas XI Program Keahlian Akuntansi SMK Negeri 1 Sidenreng Rappang.

\section{Pembahasan}

a. Pengaruh Kemandirian belajar $\left(\mathbf{X}_{1}\right)$ secara Parsial terhadap Prestasi belajar (Y)

Kemandirian belajar merupakan salah satu faktor penunjang keberhasilan siswa dalam mencapai prestasi belajar yang optimal. Seorang siswa yang memiliki kemandirian belajar mampu memahami diri sendiri, umumnya para siswa yang memiliki pemahaman diri yang positif cenderung berhasil secara akademis. Hal ini sesuai dengan pendapat:

Mulyadi (2018:241) menyatakan bahwa siswa harus memiliki kemandirian belajar yang baik untuk membantunya tetap focus dan mandiri dalam belajar sehingga mendapat prestasi belajar yang maksimal.

Berdasarkan hasil penelitian yang telah dilakukan maka diperoleh hasil dengan nilai signifikan $0,000<0,05$, maka hipotesis diterima, berarti kemandirian belajar secara parsial berpengaruh signifikan terhadap prestasi belajar siswa kelas XI program keahlian akuntansi SMK Negeri 1 Sidenreng Rappang. Sumbangan efektif Kemandirian belajar (X1) terhadap Prestasi belajar siswa (Y) sebesar 30persen.

Dengan demikian apabila siswa kelas XI program keahlian akuntansi di SMK Negeri 1 Sidenreng Rappang memiliki kemandirian belajar yang tinggi maka akan meningkatkan pencapaian prestasi belajar akuntansi begitupun sebaliknya apabila kemandirian belajar rendah maka prestasi belajar akuntansi yang dicapai rendah.

\section{b. Pengaruh Motivasi belajar $\left(\mathbf{X}_{2}\right)$ secara Parsial terhadap Prestasi belajar (Y)}

Motivasi mempunyai arti yang sangat penting dalam belajar. Karena dengan adanya motivasi dalam belajar, siswa akan lebih semangat dalam belajar. Bila seseorang telah memiliki motivasi dalam belajar, maka siswa akan berusaha belajar dengan baik dan tekun. (Saefullah, 2012) motivasi belajar adalah pendorong seseorang untuk belajar, motivasi timbul karena adanya keinginan atau kebutuhan dalam diri siswa untuk mencapai prestasi belajar.

Berdasarkan hasil penelitian yang telah dilakukan maka diperoleh hasil berdasarkan nilai signifikan $0,004<0,05$, maka hipotesis diterima, berarti motivasi belajar secara parsial berpengaruh signifikan terhadap hasil belajar akuntansi siswa kelas XI program keahlian akuntansi SMK Negeri 1 Sidenreng Rappang. 
Sumbangan efektif motivasi belajar (X1) terhadap prestasi belajar siswa (Y) sebesar 9,7persen.

\section{c. Pengaruh Kemandirian belajar $\left(\mathbf{X}_{1}\right)$ dan Motivasi belajar $\left(\mathbf{X}_{2}\right)$ secara Simultan terhadap Prestasi belajar (Y)}

Hasil penelitian diperoleh yaitu kemandirian belajar dan motivasi belajar secara simultan berpengaruh positif dan signifikan terhadap prestasi belajar dengan koefisien determinasi $\left(\mathrm{R}_{2}\right)$ yang diperoleh sebesar 0,538. Hal ini menunjukkan bahwa kemandirian belajar dan motivasi belajar berpengaruh secara simultan terhadap prestasi belajar sebesar 53,8 persen sedangkan 46,2 persen dipengaruhi oleh variabel lain yang tidak terdapat dalam penelitian ini. Hasil uji $\mathrm{F}$ diperoleh nilai $\mathrm{R}$ square sebesar 36,641 dengan nilai signifikansi $0,000<0,05$. Artinya bahwa kemandirian belajar dan motivasi belajar memiliki peranan penting dalam prestasi belajar siswa.

\section{d. Variabel yang Dominan Mempengaruhi \\ Prestasi belajar.}

Berdasarkan hasil perhitungan variabel kemandirian belajar menggunakan SPSS 25 diperoleh koefisien determinasi parsial $r^{2}=$ 0,471 atau 47 persen dengan nilai signifikan $0,000<0,05$. Hal ini berarti bahwa pengaruh kemandirian belajar terhadap prestasi belajar adalah 47persen. Hasil perhitungan variabel motivasi belajar diperoleh nilai determinasi parsial $\mathrm{r}^{2}=0,339$ atau 33persen dengan nilai signifikan $0,004<0,05$. Hal ini berarti bahwa pengaruh motivasi belajar terhadap prestasi belajar adalah 39persen. Dengan demikian dapat disimpulkan bahwa kemandirian belajar lebih dominan berpengaruh terhadap prestasi belajar siswa kelas XI Program Keahlian Akuntansi SMK Negeri 1 Sidenreng Rappang.

\section{SIMPULAN DAN SARAN Simpulan}

Berdasarkan hasil dari penelitian dan pengolahan data, maka disimpulkan hasil akhir dari penelitian sebagai berikut:

1. Kemandirian belajar siswa tergolong dalam kategori baik. Meskipun demikian masih terdapat kurangnya rasa percaya diri siswa terhadap kemampuan yang dimilikinya, usaha siswa untuk mengembangkan potensinya dan rasa percaya diri dalam melaksakan tugas secara mandiri yang menunjukkan bahwa siswa tidak memahami materi yang disampaikan oleh guru dan mereka takut untuk bertanya.
2. Motivasi belajar siswa tergolong dalam kategori baik. Meskipun demikian penghargaan dalam belajar berupa pujian yang diberikan oleh siswa masih kurang disamping itu adanya situasi lingkungan tempat mereka belajar tidak mendukung.

3. Prestasi belajar siswa tergolong sangat baik. Dimana nilai rapor semester genap siswa Program Keahlian Akuntansi di SMK Negeri 1 Sidenreng Rappang tahun ajaran 2018/2019 rata-rata baik serta tidak ada siswa yang memperoeh nilai di bawah Kriteria Ketuntasan Minimal yang telah ditentukan.

4. Hasil analisis regresi linear berganda diperoleh persamaan regresi $Y=22,313+0,502 X_{1}+0,371 X_{2}$. Artinya jika variabel kemandirian belajar dan motivasi belajar dianggap sama dengan nol, maka variabel prestasi belajar sebesar 22,313, sedangkan variabel kemandirian belajar $\left(\mathrm{X}_{1}\right)$ berpengaruh positif terhadap prestasi belajar (Y).

5. Hasil Koefesien determinasi menunjukkan bahwa, nilai $\mathrm{R}^{2}$ adalah sebesar 0,538 atau 53,8 persen. Hal ini berarti bahwa pengaruh kontribusi kemandirian belajar dan motivasi belajar terhadap prestasi belajar adalah sebesar 53,8 persen sedangkan sisanya sebesar 46,2 persen dipengaruhi oleh faktor lain

6. Hasil Uji $F$ diketahui bahwa $F$ hitung sebesar 36.641 lebih besar dibandingkan $\mathrm{F}$ tabel. $\mathrm{F}$ tabel diperoleh sebesar 3,14 dengan taraf signifikan $0,000<0,05$. Untuk menguji hipotesis dilakukan dengan membandingkan antara $\mathrm{F}$ hitung dengan $\mathrm{F}$ tabel, dimana $\mathrm{F}$ tabel diperoleh sebesar 3,14 dengan demikian nilai $\mathrm{F}$ hitung sebesar 36.641 lebih besar dibandingkan $\mathrm{F}$ tabel dengan taraf signifikan sebesar 0,000 lebih kecil dari $\mathrm{a}=$ 0,05. Hal ini berarti bahwa hipotesis diterima atau dengan kata lain kemandirian belajar dan motivasi belajar secara simultan berpengaruh positif dan signifikan terhadap prestasi belajar siswa kelas XI Program Keahlian Akuntansi SMK Negeri 1 Sidenreng Rappang.

\section{Saran}

Berdasarkan kesimpulan yang telah dikemukakan, maka peneliti memberikan saran sebagai berikut:

1. Guru berperan aktif mengembangkan kemandirian belajar dan motivasi belajar 
yang dimiliki siswa, melalui pembelajan di dalam kelas agar tercapainya prestasi belajar yang maksimal.

2. Siswa dapat mengembangkan materi pelajaran yang diberikan oleh guru sehingga memiliki wawasan yang lebih luas sehingga dapat tercapai prestasi belajar yang optimal.

\section{DAFTAR RUJUKAN}

Abu Ahmadi. (2004). Teknik Belajar yang Efektif. Jakarta: PT. Rineka Cipta

Ali, M \& Asrori, M. (2016). Psikologi Remaja Perkembangan Peserta Didik. Jakarta: PT. Bumi Aksara

Desmita. (2017). Psikologi Perkembangan Peserta Didik. Bandung: PT. Remaja Rosdakarya.

Dimyati dan Mudjiono. (2015). Belajar \& Pembelajaran. Jakarta: Rineka Cipta

Mulyadi, Seto. (2018). Psikologi Pendidikan: Dengan Pendekatan teori-teori baru dalam psikologi. Depok: PT. Raja Grafindo Persada

Ghozali, I. (2011). Aplikasi Analisis Multivariate dengan Program SPSS. Semarang: Badan Penerbit Universitas Diponegoro

Haris Mujiman. (2007). Manajemen Pelatihan Berbasis Belajar Mandiri. Yogyakarta: Mitra Cendekia

Helmawati. 2016. Pendidikan Keluarga. Jakarta: Rajawali.

Hurlock, E. B. (2011). Psikologi Perkembangan. Jakarta: Erlangga.

Johnson, E. B. (2009). Contextual Teaching \& Learning. Bandung: Mizan Learning Center.

Morrison, G. (2012). Dasar-Dasar Pendidikan Anak Usia Dini. Jakarta: PT Indeks.

Mudjiman, H. (2011). Manajemen Pelatihan Berbasis Belajar Mandiri. Yogyakarta: Pustaka Pelajar.

Narimawati, U. (2008). Metodologi Penelitian Kualitatif dan Kuantitatif: Teori dan Aplikasi. Bandung: Agung Media.

Rahmatullah. (2018). Pembelajaran Ekonomi Berjatidiri Bangsa. JEKPEND: Jurnal Ekonomi Dan Pendidikan, 1(1), 10-16. https://doi.org/10.26858/jekpend.v1i1.5055

Rahmatullah, \& Inanna. (2017). Identifikasi Nilai-Nilai Ekonomi Sebagai Dasar Merumuskan Materi Pengantar Ilmu Ekonomi Berjatidiri Bangsa. Prosiding Seminar Nasional Lembaga Penelitian UNM, 700-704.

Rahmatullah, \& Inanna. (2018). Strategi Belajar

DOI:10.26858/jekpend.v3i2.14320
Mengajar. Badan Penerbit UNM.

Rahmatullah, Inanna, Sahade, Nurdiana, Fajriani Azis, \& Bahri. (2020). Utilization of Digital Technology for Management Effectiveness Micro Small and Medium Enterprises. International Journal of Scientific \& Technology Research, 9(4), 1358-1362. Retrieved from www.ijstr.org

Ridwan \& Akdon. (2009). Rumus Dan Data Dalam Analisis Statistika. Bandung: Alfabeta.

Saefullah. 2012. Psikologi Perkembangan dan Pendidikan. Bandung: CV Pustaka Setia.

Sardiman. (2016). Interaksi dan Motivasi Belajar Mengajar. Jakarta: Raja Grafindo Persada.

Silberman, M. (2014). Active Learning. Yokyakarta: Pustaka Insan Madani.

Slameto. 2010. Belajar dan Faktor-Faktor yang Mempengaruhinya. Jakarta: Rineka Cipta.

Slavin, R. E. (2009). Psikologi Pendidikan: Teori Dan Praktek. Jilid 2. Jakarta: PT. Indeks.

Sugiyono. 2017. Metode Penelitian Pendidikan. Bandung: Alfabeta.

Sukmadinata, Nana Syaodih. (2009). Landasan Psikologi ProsesPendidikan. Bandung: Remaja Rosdakarya.

Suparno, S. A. (2000). Membangun Kompetensi Belajar. Jakarta: Direktorat Jendral Pendidikan Tinggi Departemen Pendidikan Nasional.

Syah, Muhibbin. 2012. Psikologi Belajar. Jakarta: Raja Grafindo Persada.

Tirtarahardja, U. \& La Sulo. (2008). Pengantar Pendidikan. PT. Rineka Cipta : Jakarta.

Trijono, R. (2015). Metodologi Penelitian Kuantitatif. Jakarta: Papas Sinar Sinanti.

Uno, Hamzah B., (2017). Teori Motivasi dan Pengukurannya. Jakarta: PT. Bumi Aksara.

Wahab, Rosmalina. (2016). Psikologi Belajar. Jakarta: Raja Grafindo Persada.

Yamin, Martinis. 2006. Strategi Pembelajaran Berbasis Kompotensi. Jakarta: GP Press.

Yulianti, Thaief, I., \& Rahmatullah. (2019). Contextual Teaching Learning Dalam Pembelajaran Ekonomi Contextual Teaching Learning in Economic Learning. Pinisi Business Administration Review, l(2), 117-124. 